\title{
Maciej Libich
}

Uniwersytet Warszawski

(iD http://orcid.org/0000-0002-8536-3315

\section{"Misterium bólu" Dzieciństwo w prozie Gézy Csátha}

\author{
"The Rite of Pain" \\ Childhood in the Works of Géza Csáth
}

Abstract: The author of the article analyses the image of childhood in the short stories of Geza Csáth (1887-1919) in order to demonstrate how the Hungarian modernist writer critiques and subverts modern conceptualisations of childhood as idyllic and innocent. By referencing the works of Sigmund Freud, Jacques Lacan and, most importantly, Melanie Klein, the author proves that Csáth's short stories about childhood are strongly rooted in psychoanalytical thought, with some of them being surprisingly similar to now-canonical descriptions of psychoanalytical case studies. As it is shown, in such stories as Black Silence, Matricide or Little Emma, the modernist writer portrays his young characters as subject to the same suffering as adults, and as evil from their earliest years.

Key words: Géza Csáth, modernism, psychoanalysis, Melanie Klein, childhood

Streszczenie: Artykuł jest próbą opisania dzieciństwa, którego niepokojący obraz, zaprzeczający nowożytnym wyobrażeniom o sielankowości najmłodszych lat życia, wyłania się z opowiadań Gézy Csátha (1887-1919), węgierskiego modernistycznego pisarza. Sięgając po prace najważniejszych psychoanalityków i psychoanalityczek - m.in. Zygmunta Freuda i Jacques'a Lacana, ale przede wszystkim Melanie Klein - autor dowodzi, że literatura Csátha poświęcona dzieciom i dzieciństwu silnie czerpie z myśli psychoanalitycznej, a poszczególne prozy wydają się niekiedy zaskakująco zbieżne z opisami klinicznych przypadków. Interpretując opowiadania takie, jak: Czarna cisza, Matkobójstwo czy Mała Emma, autor pokazuje też, że zdaniem Csátha dzieci narażone są na 
takie samo cierpienie jak dorośli, a w człowieku, szczególnie tym najmłodszym, jeszcze nieuformowanym, widzi siedlisko zła.

Słowa kluczowe: Géza Csáth, modernizm, psychoanaliza, Melanie Klein, dzieciństwo

"Z utratą wiary w aseksualność dzieci utraciliśmy również wiarę w »raj dzieciństwa «"1 - pisała w Psychoanalizie dzieci Melanie Klein. Jej badania i praktyka kliniczna, inspirowane pracami Zygmunta Freuda, wyraźnie potwierdziły, że perwersyjna seksualność jest powszechna nie tylko wśród dorosłych, lecz także wśród niemowląt, kilkulatków i młodzieży w okresie dojrzewania ${ }^{2}$.

Choć już wcześniej ulegał przeobrażeniom, kulturowy konstrukt idyllicznego dzieciństwa - który przez setki lat opierał się na przeświadczeniu, że dzieci są niewinne, czyste i z tego względu nie mają potrzeb seksualnych, a sfera życia erotycznego zarezerwowana jest wyłącznie dla dorosłych ${ }^{3}$ - ostatecznie upadł w momencie, w którym psychoanaliza stała się powszechną praktyką terapeutyczną i jednym z najważniejszych prądów myślowych XX wieku. Do świadomości społecznej zaczęło docierać, że seksualność dzieci jest stałym elementem rozwoju człowieka ${ }^{4}$, przede wszystkim zaś - że choć między dzieciństwem a dorosłością da się wytyczyć pewne granice, niektóre doświadczenia okazują się wspólne dla obu tych etapów życia, a sam okres młodości nie jest wcale, jak się wcześniej zdawało, pozbawiony trosk. Wręcz przeciwnie. Dzieciństwo - przekonują Freud oraz Klein - przesycone jest poczuciem winy, seksualnymi kompleksami i nieuświadomionymi traumami, które przepracowuje się do końca życia 5 .

Nie trzeba było długo czekać, aby skutki tego procesu stały się widoczne w literaturze; koniec XIX wieku zwiastuje odejście od

${ }^{1}$ M. Klein: Pisma. T. 2: Psychoanaliza dzieci. Przeł. M. Lipińska, M. Żylicz, H. Grzegołowska-Klarkowska. Wstęp W. Hańbowski. Gdańskie Wydawnictwo Psychologiczne, Gdańsk 2007, s. 3.

2 J. Rose: The Case of Peter Pan or The Impossibility of Children's Fiction. University of Pennsylvania Press, Philadelphia 1993, s. 14.

${ }^{3}$ Zob. Ph. Ariès: Historia dzieciństwa. Przeł. M. Ochab. Marabut, Gdańsk 1995, s. 104-129.

${ }^{4}$ M. Bieńko: Międzygeneracyjny kontekst wychowania seksualnego w rodzinie $z$ perspektywy młodego pokolenia, czyli kłopotliwe rozmowy rodziców i dzieci na temat intymności. „Studia Socjologiczne” 2017, nr 2, s. 218.

${ }^{5}$ J. Rose: The Case..., s. 12. 
tradycji sentymentalnych i romantycznych, a obraz sielankowego raju najwcześniejszych lat coraz częściej zastępuje wizja dzieciństwa tyleż "melancholijnego, przepełnionego samotnością i cierpieniem", co wprost piekielnego, przesiąkniętego złem. Jednym z pierwszych pisarzy, którzy korzystali z takich przedstawień - a w swoich utworach przekraczali zastane techniki opisu, przyjmując nową optykę - był prozaik Géza Csáth (właśc. József Brenner), jeden z najważniejszych węgierskich artystów XX wieku. Jego twórczość, bez wątpienia trudna w lekturze ze względu na brak jakichkolwiek tematów tabu, wyrastała z przeświadczenia, że dzieciństwo ma fundamentalny wpływ na życie dorosłego i nawet pojedyncze wydarzenie z tego okresu potrafi ukształtować późniejszą osobowość człowieka. W prozie Csátha dominują okrucieństwo i ból, międzyludzkie relacje opierają się na przemocy, seksualne perwersje są na porządku dziennym, a traumy z nimi związane prześladują bohaterów i bohaterki przez dekady. Można by wręcz powiedzieć, że postaci z opowiadań Csátha - nierzadko cierpiące $\mathrm{z}$ powodu nierozwiązanego konfliktu edypalnego - niekiedy do złudzenia przypominają pacjentów opisywanych przez Klein. Obserwacje czynione przez pisarza wyprzedzają jednak badania psychoanalityczki o kilka dekad, poza tym wnioski, które wysnuwają oboje, są zgoła odmienne. Niemniej, teksty autora Opium wyraźnie dowodzą, że we wczesnych latach życia można nie tylko doświadczać wielkiego zła, lecz także je czynić, i w tym sensie ukazują zarówno konsekwencje międzyludzkich relacji (przede wszystkim między członkami rodziny), jak i mroczne strony człowieczeństwa, którego kondycja - zdaniem autora Matkobójstwa - godna jest co najwyżej pogardy ${ }^{7}$.

Do takiego przekonania niewątpliwie doprowadziła go właśnie psychoanaliza, którą zgłębiał jako student medycyny specjalizujący się w psychiatrii. Urodzony w 1887 roku Csáth dorastał w czasie gwałtownego rozwoju teorii psychoanalizy, choć nie doczekał pełnego rozwinięcia myśli Freuda - w 1919 roku popełnił samobójstwo. $\mathrm{O}$ jego tragicznej biografii powiedziano już wiele ${ }^{8}$, nie ma więc potrzeby rekonstruować jej szczegółowo. Warto jednak przywołać kilka momentów węzłowych. Csáth przyszedł na świat w Suboticy

${ }^{6}$ G. Leszczyński: Kulturowy obraz dziecka $i$ dzieciństwa w literaturze drugiej połowy XIX i w XX wieku. Wydawnictwo Wydziału Polonistyki Uniwersytetu Warszawskiego, Warszawa 2006, s. 106.

7 A. Wiedemann: Człowieczeństwo i czary. https://www.dwutygodnik.com/ artykul/6662-czlowieczenstwo-i-czary.html [dostęp: 14.03.2021].

${ }^{8}$ Zob. np. E. Cygielska: Csáth. W: G. Csáth: Opium. Przeł. E. Cygielska [et al.]. Państwowy Instytut Wydawniczy, Warszawa 2016, s. 370-382. 
(dzisiejszej Szabadce), gdzie wychowywał się razem ze swoim kuzynem, wybitnym pisarzem Dezső Kosztolányim. Gdy miał osiem lat, zmarła jego matka Etelka Descy; wydarzenie to wywarło ogromny wpływ na życie i literaturę pisarza, powracało ono zarówno w autobiograficznych zapiskach, jak i w licznych opowiadaniach. Dziesięć lat później Csáth przeniósł się na studia do Budapesztu. Początkowo chciał studiować na akademii muzycznej, lecz nie dostał się do niej, rozgoryczony zapisał się więc na medycynę. Był - jak widać wszechstronnie wykształcony i uzdolniony artystycznie: malował, grał na kilku instrumentach, a także pisał; już jako czternastolatek publikował recenzje muzyczne $\mathrm{w}$ lokalnym dzienniku'. Po przeprowadzce do stolicy nie porzucił aspiracji literackich - mimo że większość czasu musiał poświęcać medycynie, drukował szkice, recenzje i opowiadania na łamach legendarnego pisma „Nyugat” (pol. "Zachód"), powstałego w 1908 roku, którego głównym celem była odnowa kultury węgierskiej i przeniesienie na jej grunt europejskich prądów literackich ${ }^{10}$. Csáth natychmiast stał się ważną osobą w periodyku, był bowiem modernistą tout court - czerpał z symbolizmu, neoromantyzmu, interesowała go sfera nadrealna, a do swoich opowiadań nieustannie wplatał wątki oniryczne ${ }^{11}$. W tym sensie jego twórczość wpisywała się $w$ tendencje, jakie wyznaczali pozostali autorzy drukujący w „Nyugacie”, np. Endre Ady, Mihály Babits, a zwłaszcza Gyula Krúdy, który eksperymentował z przekształcaniem baśni i legend w opowieści o perypetiach młodego flâneura.

W „Nyugacie" publikowali jednak nie tylko poeci, prozaicy i krytycy literaccy. Między 1908 a 1939 rokiem w piśmie tym ukazało się aż pięćdziesiąt artykułów z zakresu psychoanalizy ${ }^{12}$, za co odpowiedzialny był w głównej mierze Sándor Ferenczi, jeden z pierwszych uczniów Freuda i przez długie lata jego najbliższy współpracownik. Ferenczi był też recenzentem rozprawy naukowej Csátha pt. Psychiczny mechanizm chorób umystowych $(1911)^{13}$ - inspirowanej wczes-

9 Ibidem, s. 372.

${ }^{10}$ E. Cygielska: „Nyugat”. „Literatura na Świecie” 2002, nr 7-8-9, s. 257.

${ }_{11}$ Zob. M. Libich: Opium, czyli katastrofa. „Literatura na Świecie” 2019, nr 9-10, s. 340-349.

${ }^{12}$ L. Magnone: Dywan z Bukowiny. Drogi rozpowszechniania sie freudyzmu w Europie Środkowej. W: Problemy literatury i kultury modernizmu w Europie Środkowo-Wschodniej (1867-1918). T. 1: Teksty doświadczenia. Red. E. Paczoska, I. Poniatowska, M. Chmurski. Wydawnictwa Uniwersytetu Warszawskiego, Warszawa 2017, s. 371.

${ }^{13}$ G. Csáth: Dziennik chorej umysłowo. Przeł. W. Obiała. „Literatura na Świecie” 2015, nr 3-4, s. 309-341. 
nym Freudem, a także doktoratem Carla Gustava Junga, w której dostrzec można było niespotykany dotychczas „splot języków medycyny, fikcji i autobiografii"14 - i docenił ją właśnie za formalną oryginalność, ale także za próbę połączenia psychiatrii i psychoanalizy z literaturą ${ }^{15}$. Początkowo niechętny medycynie Csáth odnalazł się zatem jako psychoanalityk i psychiatra. Gdy po studiach otrzymał etat w renomowanej klinice psychiatrycznej Ernő Moravcsika, praca z chorymi zafascynowała go do tego stopnia, że uczynił z niej jeden $z$ głównych tematów swoich opowiadań. A pisał regularnie: szybko wydał dwa zbiory krótkich próz, docenione przez krytykę, prowadził też dziennik, w którym szczegółowo opisywał liczne miłosne podboje; diariusz wypełniony a to najprostszą buchalterią, a to marzeniami, snami czy erotycznymi fantazjami. Mniej więcej w tym samym czasie zaczął eksperymentować z narkotykami, tuż po tym, jak lekarz stwierdził u niego gruźlicę - również ten epizod z jego życia został opisany w dzienniku. Wzburzony diagnozą Csáth sięgnął po morfinę; był już od niej silnie uzależniony, zanim dowiedział się, że rozpoznanie lekarskie było błędne. Przez lata próbował się leczyć, aczkolwiek dość niechętnie i nieskutecznie, przez co popadał w coraz głębszy nałóg, aż wreszcie w 1918 roku przeszedł poważne załamanie nerwowe. Trafił do szpitala psychiatrycznego, z którego uciekł; gdy udało mu się wrócić do domu, zastał w nim swoją żonę... i zastrzelił ją. Po raz kolejny znalazł się w szpitalu, z którego znów uciekł. Zatrzymany na serbskiej granicy przez żołnierzy, po krótkiej szarpaninie rozgryzł ampułkę z cyjankiem i zmarł, miał 32 lata $^{16}$.

Wstrząsające koleje życia Csátha znajdują odzwierciedlenie w jego quasi-autobiograficznej twórczości, w której tekstualna fikcja nierozerwalnie splata się z prawdziwym życiem, ale i głęboko skrywanymi fantazjami autora ${ }^{17}$; postaci z jego próz to często narkomani, alkoholicy, dręczyciele zwierząt i sadyści, a także okrutni mordercy, którzy dążą do spełniania swoich seksualnych pragnień. Znaczna część z nich to jeszcze dzieci lub nastolatkowie, którzy zachowują się tak samo jak doświadczeni życiem dorośli i w drastycznych okolicznościach dochodzą do wniosku, że nigdy nie zaznają szczęścia. Taki dotkliwy los jest ukazany w dwóch utworach Csátha: Świniobiciu

${ }^{14}$ M. Chmurski: Błądzenie Gézy Csátha: między autobiografizmem, fikcja a autoanaliza. "Autobiografia” 2019, nr 2, s. 75.

${ }^{15}$ E. Cygielska: Csáth..., s. 374.

16 Ibidem, s. 376.

${ }_{17}$ M. Chmurski: Rąbek nieskończoności. „Literatura na Świecie” 2015, nr 3-4, s. 343. 
i Józsice. Pierwsze z tych opowiadań - zaledwie kilkustronicowe otwiera debiutancki zbiór Csátha i nie jest jeszcze tak silnie inspirowane psychoanalizą jak późniejsze prozy. Pisarz przywołuje w nim historię piętnastoletniej Maris, służącej w ziemiańskim domu, w którym z okazji tytułowego świniobicia zjawia się rzeźnik. Gdy mężczyzna kończy pracę, niespodziewanie gwałci dziewczynę, która musiała pomagać mu w pracy: „Ledwie Maris weszła do kuchni, rzeźnik objął ją w talii i przylgnął do niej całym ciałem. [...] Pół godziny później wyszła na podwórze z chustką zsuniętą na oczy" $(\mathrm{s} .10)^{18}$. Naturalistyczny i mocno eliptyczny opis podkreśla okrucieństwo tej sceny, a jednocześnie zdumiewa chłodem spojrzenia. Csáth nie dokonuje bowiem oceny moralnej opisywanego zdarzenia - czerpiąc z najwcześniejszych ustaleń freudyzmu, chce zobrazować ludzką popędliwość i pokazać jej destrukcyjny charakter. Portretuje przy tym osobę zawieszoną między dzieciństwem a dorosłością. W przypadku Maris utrata dziewictwa w wyniku gwałtu zdefiniuje jedno i drugie: jej młodość będzie odtąd naznaczona przemoca, której doznała, dorosłość natomiast - próbą przepracowania traumy.

Inaczej jest w Józsice. To nieco dłuższa proza, w której pięcioletni chłopiec, alter ego autora ( $\mathrm{w}$ młodości na Csátha wołano właśnie "Józsika"19), opowiada o swojej codzienności. Czas spędza głównie z babcią i nianią, które wychowują go wspólnie, ponieważ jego rodzice zmarli tuż po jego narodzinach. „Uwielbiałem to łaskotanie porannego światła, kiedy moja dobra niania na kanapie w dobrze wywietrzonej i posprzątanej jadalni przystępowała do zrobienia mi toalety" (s. 146) - mówi narrator, szkicując na pierwszych stronach utworu dość naiwny portret beztroskiego dzieciństwa. Prędko jednak burzy ten obraz. W pewnym momencie wypowiada podszyte ironią zdania: „Mój Boże, skończyłem pięć lat, jakże się zmieniłem, jak ten czas zleciał! [...] Czy przytrafiło mi się coś pięknego, wielkiego? Nie, nic. [...] Ile czasu musi upłynąć, żebym dorósł, żebym się dowiedział, dlaczego warto żyć" (s. 149), które świadczą o tym, że do swojego dzieciństwa ma raczej podejrzliwy stosunek. Przede wszystkim jednak prześladuje go lęk przed obcymi mężczyznami, którego nie potrafi opanować: „mniej więcej co czwarty, piąty mężczyzna budzi [mój - M.L.] lęk, zwłaszcza gdy nosi brodę" (s. 150) - mówi chłopiec. Jego obawy dają się przy tym dość łatwo wytłumaczyć. Dzieci - zauważa Klein we wspomnianej Psychoanalizie dzieci - mają bowiem o wiele ostrzejsze lęki niż dorośli, a znaczną część ich

${ }^{18}$ Numery stron podaję za cytowanym wydaniem: G. Csáth: Opium...

19 E. Cygielska: Csáth..., s. 372. 
energii pochłania próba zapanowania nad strachem. Dlatego też, gdy walczą z lękiem, który powoduje w nich najbliższy im obiekt (najczęściej rodzic), swoje obawy zaczynają wiązać z odleglejszymi przedmiotami i osobami: „silnie neurotyczne dziecko, które przez większość czasu czuje się zagrożone i wobec tego ciągle poszukuje wokół siebie »złej« matki lub »złego« ojca, na każdą nieznaną osobę będzie reagowało lękiem"20. Pozostaje tylko pytanie, kogo właściwie boi się Józsika. Babci, która kategorycznie nie pozwala mu wstać od stołu i codziennie zmusza go do jedzenia, przybierając tym samym formę karzącego ojca? Czy raczej niani, która każdego ranka dokładnie myje chłopca, choć jednocześnie, wbrew jego życzeniom, wciera w jego twarz brudną wodę, w której wcześniej płukał ręce: „Niestety niania, choć wielokrotnie jej to tłumaczyłem, nie chciała przyznać, że ten zakorzeniony w niej nawyk jest beznadziejny" (s. 147). Ta wypowiedź wydaje się interesująca choćby dlatego, że pozwala zderzyć opowieść o Józsice z opisywanym przez Klein klinicznym przypadkiem kilkuletniego Kennetha uwiedzionego przez swoja opiekunkę, która - co szczególnie ciekawe - miała kompulsywne, ściśle określone wymagania i nawyki dotyczące czystości dziecka ${ }^{21}$. Kazała mu również obserwować, jak sama bierze kąpiel i pocierać swoje genitalia. Znaczący wydaje się więc fakt, że omawiane opowiadanie Csáth zadedykował swojej niani - ten autorski gest zachęca do autobiograficznych odczytań.

Ataki lękowe Józsiki nasilają się $\mathrm{w}$ nocy. $\mathrm{W}$ ciemnościach zaczyna widzieć wtedy czyhających na niego mężczyzn, którzy "chowają się pod wieszakami, wchodzą pomiędzy ubrania, podciągając nogi, żeby nie było ich widać; albo wpełzają pod łóżko, w najmroczniejszy kąt" (s. 153) i chcą zrobić mu krzywdę. Podobne przypadki opisywała w swojej pracy Klein. Jej pacjentki - czteroletnie Trude i Ruth - w analogiczny sposób opowiadały o swoich nocnych lękach i wspominały o niepokojących postaciach, które chciały zrobić im krzywdę. Zdaniem psychoanalityczki lęki te miały świadczyć o rozwijającym się kompleksie Edypa i były „równoważne odczuwanym przez chłopców lękom kastracyjnym"22. Czy w przypadku Józsiki chodziłoby zatem o kompleks kastracyjny? Być może. Zgadzałoby się to $\mathrm{z}$ ustaleniami Freuda, wedle którego lęk ten mają odczuwać chłopcy $\mathrm{w}$ okresie fallicznym, a więc między 4. a 5. rokiem życia. Interpretację tę potwierdzałoby również jeszcze jedno

${ }^{20}$ M. Klein: Pisma. T. 2: Psychoanaliza dzieci..., s. 24.

${ }^{21}$ Ibidem, s. 64.

${ }^{22}$ Ibidem, s. 31. 
charakterystyczne wyobrażenie młodego bohatera, a mianowicie postać prześladującego go rudobrodego mężczyzny (która powraca zresztą w licznych opowiadaniach Csátha). „Boję się zwłaszcza jednego" - wyznaje narrator, po czym dodaje: „Niskiego człowieka z rudą broda. Ma zielone oczy. Jego wzrok mnie przeraża. [...] I pod długą brązową peleryną zaciska w pięści czerwone ręce. Albo trzyma nóż, którym zwykł popełniać zbrodnie" (s. 151). Nóż w tej scenie symbolizować mógłby zarówno potencjalne narzędzie kastracji, ale i fallusa ojca, który stanowi zagrożenie dla chłopca $-\mathrm{z}$ jednej strony widmowe i fantazmatyczne, lecz z drugiej niewątpliwie realne. Bo przecież ojciec, choć martwy, jest ciągle obecny w życiu swojego syna i patrzy na niego ze zdjęć, napawając go nieuświadomionym lękiem i coraz silniej chwiejąc jego tożsamością. Być może dlatego, aby ocalić swoja podmiotowość, chłopiec żywi tak silne upodobanie do przeglądania się w lustrze: „spędzałem przed lustrem dużo więcej czasu, niż wypada" (s. 147) - mówi zawstydzony. Im częściej widzi siebie jako człowieka pękniętego i rozczłonkowanego, któremu grozi kastracja, tym chętniej spogląda na swoje lustrzane odbicie, aby doświadczyć „siebie-ciała jako porządku i jedności”"23.

Podobnie znerwicowane postaci są częstymi bohaterami próz Csátha. Na przykład kilkuletni narrator krótkiego, impresjonistycznego wręcz opowiadania Sobotnie wieczory - równie melancholijnego co Józsika i tak samo przesiąkniętego niepokojem - zdradza, że co noc nad jego snem czuwa Piaskun, olbrzymia i przerażająco brzydka postać rodem z ludowych podań. Choć nie jest on przyczyną tak wyraźnego poczucia zagrożenia jak rudobrody mężczyzna, nie ulega wątpliwości, że jego obecność jest powodem lęków dziecka. Można oczywiście potraktować Piaskuna jako symbol nieznanego, metaforę tajemniczości życia, lecz również pokusić się o interpretację w kluczu psychoanalitycznym i uznać go za symptom rozwijającej się sytuacji lękowej. Neurotyczny jest również czteroletni bohater opowiadania O tym, jak zabładzitem... - zadedykowanego zmarłej matce autora - który sam siebie określa mianem "małego nerwowego dziecka” (s. 179). Sformułowanie to zapożyczył od swojego ojca, co zdaje się wiele mówić o źródle jego dość szczególnego zachowania: chorobliwie wstydzi się on przed własną matką i nie jest w stanie wręczyć jej nawet bukietu kwiatów, który dla niej zerwał, gdy zgubił się podczas samotnego spaceru. W końcowych fragmentach opowiadania dowiadujemy się, że chłopcu, a raczej dojrzałemu już mężczyźnie, nie

${ }^{23}$ P. Dybel: Samouwiedzenie w lustrze. Program antropologii psychoanalitycznej we wczesnych pismach Jacques'a Lacana. „Przegląd Filozoficzny” 1996, nr 4, s. 15. 
udało się wyleczyć dręczącej go neurozy. Dopiero po kilku dekadach decyduje się, by opisać popołudnie, podczas którego nie potrafił, lub nieświadomie nie chciał, wrócić do domu - tak jakby jedynie upływ czasu umożliwiał podjęcie próby zmierzenia się z traumą - mimo że $\mathrm{w}$ ciągu lat sytuacja ta powtarzała się wielokrotnie $\mathrm{w}$ bardzo podobnej formie. Nie jest to zaskakujące. Pojedyncze sytuacje lękowe $\mathrm{z}$ dzieciństwa potrafią zmienić się $\mathrm{w}$ długotrwałe zaburzenia, te zaś w dorosłym życiu przybierają formę kompulsywnych odruchów, powracających sytuacji, nieuświadomionych awersji czy fobii ${ }^{24}$. Csáth opisuje to w swojej prozie, kreując przy tym dorosłych narratorów, którzy przytaczają dręczące ich wspomnienia.

Nerwice, zaburzenia i choroby psychiczne mające swoje źródło w dzieciństwie znał zresztą świetnie dzięki lekarskiej praktyce, której poświęcił jedno ze swoich najmroczniejszych opowiadan Czarna ciszę. Zaczyna się ono od zwierzenia pacjenta leżącego na kozetce: „Wyjaśnię panu, doktorze, o co chodzi. Chodzi o mojego braciszka, rumianego chłopczyka o jasnych włosach i ciemnych oczach [...]. I jeszcze o tę czarną ciszę" (s. 12) - mówi mężczyzna. Następnie relacjonuje przerażającą transformację, jakiej uległ jego młodszy brat Richard, który z dnia na dzień stał się sadystycznym potworem: w ciągu kilku dni przypiekł żywcem kota, terroryzował rodzinę, a następnie podpalił dom miejscowego radcy. Narrator jest przekonany, że Richarda opętały demoniczne moce, reprezentowane przez tytułową "czarną ciszę", i prędko dochodzi do wniosku, że musi ocalić świat przed złem, jakie nosi w sobie jego brat. Niedługo potem zabija go, przekonany, że czyni dobrze. Przeświadczenie to okazuje się jednak czystą ułudą. Na jaw wychodzi, że uduszony chłopiec w niczym nie przypomina opisywanej bestii, a do morderstwa skłoniła narratora - przynajmniej wedle jego słów - tajemnicza czarna cisza. W najprostszym odczytaniu jest to więc opowieść o schizofreniku, który podczas sesji u psychoterapeuty lub psychiatry przywołuje traumatyczne zdarzenia $\mathrm{z}$ dzieciństwa. Co ciekawe, i w tym przypadku Csáth powstrzymuje się od moralnego osądu, by pokazać, jak wygląda świat chorego; pisarz próbuje wejść w jego skórę, a następnie wyobrazić sobie i zinternalizować jego wizje, by na koniec zderzyć jego perspektywę z rzeczywistością ${ }^{25}$. I również tym razem można postawić tezę, że Czarna cisza to opowieść o budzącej się popędliwości: piekielny szał, w jaki wpada Richard, mógłby obrazować dochodzące do głosu libido, a ogień, który poja-

${ }^{24}$ M. Klein: Pisma. T. 2: Psychoanaliza dzieci..., s. 97.

${ }^{25}$ M. Libich: Opium, czyli katastrofa..., s. 343. 
wia się zarówno w scenie torturowania kota, jak i podpalania domu - symbolizować seksualne pragnienie. Warto zresztą dodać, że niemal wszystkie prozy Csátha interpretować można jako (nieustannie ponawiane) próby opisywania popędów seksualnych, co stanie się jaśniejsze w toku analizy kolejnych opowiadań.

Czarna cisza prowokuje jednak więcej pytań. Czy opisywane zdarzenia faktycznie miały miejsce i czy pacjent naprawdę zamordował swojego brata? Jeśli tak, czy wynikało to ze zmiany zachowania Richarda, który wpadł w sadystyczną manię, czy było raczej efektem schizofrenicznych halucynacji opowiadającego? Może Richard w ogóle nie istniał, cała historia jest jedynie wymysłem mówiącego, a morderstwo - metaforą interwencji superego, które „zabija” niemoralną część osobowości człowieka? A może fantastyczna opowieść pacjenta jest tylko zawoalowanym sposobem zakomunikowania innego rodzaju traumy? Ostatnia sugestia pozwala wysnuć nieco bardziej ryzykowną interpretację, która ponownie uruchamia nawiązanie do praktyki terapeutycznej Klein. W Psychoanalizie dzieci opisała ona przypadek dwóch braci, Günthera i Franza, który pod wieloma względami przy pominał relację pacjenta u Csátha. Günther, starszy od Franza, był nieśmiałym i nieufnym dzieckiem, Franz natomiast - nadpobudliwym i agresywnym. Bracia pozostawali we wrogich stosunkach i nie potrafili nawiązać wzajemnej komunikacji. Podczas sesji analitycznych na jaw wyszło, że od wczesnego dzieciństwa utrzymywali relację seksualną: Günther, którego sadyzm był niezwykle nasilony, a przy tym skrzętnie ukrywany, zmuszał Franza m.in. do wzajemnych praktyk oralnych i masturbacyjnych. Obaj chłopcy cierpieli przez to $\mathrm{z}$ powodu nieuświadomionego poczucia winy $^{26}$. Franz na swoją krzywdę reagował agresją i zachowywał się wyjątkowo brutalnie wobec dzieci młodszych od siebie $^{27}$, Günther zaś nie odczuwał żadnych wyrzutów sumienia i obawiał się jedynie odwetu, a jego strach skłaniał go do ustawicznego ponawiania aktów przemocy. Im częściej Günther zmuszał swojego brata do wykonywania czynności seksualnych, tym silniej utwierdzał się $w$ przekonaniu, że to nie on jest ofiarą ${ }^{28}$. $W$ tym sensie jego postawa przypominałaby wyparcie pacjenta z Czarnej ciszy, który potrafiłby dostrzec jedynie ostateczną i graniczną formę czynionej przez siebie przemocy, a nie jej wcześniejsze emanacje. Zamordowanie Richarda - faktyczne czy fantazmatyczne - byłoby

${ }^{26}$ M. Klein: Pisma. T. 2: Psychoanaliza dzieci..., s. 115.

${ }^{27}$ Ibidem, s. 117.

${ }^{28}$ Ibidem, s. 116. 
w takim odczytaniu próbą powstrzymania krzywdy dziejącej się opowiadającemu.

Choć warte rozważenia ze względu na zaskakujące zbieżności, odczytanie to musi pozostać w sferze domysłów. Jedną z najistotniejszych cech twórczości Csátha jest bowiem to, że przeważnie nie oferuje ona żadnego wyjaśnienia - nigdy nie wiadomo, co rzeczywiście powodowało ludźmi czyniącymi zło, a pesymistycznego wydźwięku wszystkich utworów nie sposób ot tak zrzucić na karb epoki, w której żył i tworzył pisarz. Oczywiście, przełom XIX i XX wieku był okresem głębokiego rozczarowania przemianami następującymi po Wiośnie Ludów ${ }^{29}$, dodatkowo podsycanego myślą Arthura Schopenhauera i Fryderyka Nietzschego. Poczucie to ponad wszelką miarę wzmocniła też Wielka Wojna, która przyczyniła się do rozchwiania nerwowego autora. Niemniej pisarstwa Csátha nie sposób traktować jedynie jako produktu swych czasów. Wręcz przeciwnie. Csáth - co odróżniało go od większości pisarzy drukujących w "Nyugacie” głęboko fascynował się metafizyką zła. Przyczyna owego zła była dla niego jednak sprawą drugo- lub nawet trzeciorzędną; ciekawił go przede wszystkim fakt, że jest ono wpisane w naturę człowieka, co stwierdzał zresztą chłodno, relacjonując ludzką krzywdę i nieszczęście jak gdyby nieco z boku³1. Świadomość, że zło jest nieusuwalną częścią ludzkiego życia, musiała być jednak trudna do zniesienia, Csáth szukał więc sposobów, aby przejść nad nią do porządku dziennego. Być może dlatego z taką łatwością sięgnął po morfinę i opium, szybko doprowadzając do swojej śmierci, i być może z tego powodu tak chętnie w swoich prozach przywoływał melancholijne obrazy z dzieciństwa. Omówione utwory są tego najlepszym dowodem, a jednocześnie pokazują, że sielanka lat dziecięcych - choć wytrwale konstruowana - musi ulec rozpadowi pod naporem przytłaczającego poczucia beznadziei, które towarzyszy postaciom Csátha.

Dosadnym rozwinięciem tego przeświadczenia są dwa przerażające opowiadania - Matkobójstwo oraz Mała Emma. Pierwsze jest chyba najbardziej znaną prozą autora - do tego wręcz stopnia, że sfilmowane zostało przez Jánosa Szásza i w 1997 roku trafiło do kin pod tytułem Bracia Witmanowie. Nie jest to wprawdzie ekranizacja sensu stricto, a raczej luźna adaptacja, łącząca kilka motywów ważnych dla twórczości Csátha, poza tym dokonuje się w niej

${ }^{29}$ E. Hurnikowa: Zmierzch $w$ literaturze $i$ malarstwie austriackim na przełomie XIX i XX wieku. „Świat i Słowo” 2013, nr 2, s. 187.

30 E. Cygielska: „Nyugat”..., s. 259-260.

${ }^{31}$ M. Libich: Opium, czyli katastrofa..., s. 346. 
przesunięcie, które zmienia istotę jego twórczości. Czyny kilkunastoletnich braci Witmanów - o których więcej za moment - są bowiem tłumaczone i usprawiedliwiane przez reżysera; bestialstwo, jakiego się dopuszczają, ma swoje źródło w traumach z przeszłości. Pisarz przedstawia to odmiennie. Choć na początku zaznacza, że bracia są półsierotami wychowywanymi przez matkę, i dodaje, że „kiedy ładnym, zdrowym dzieciom wcześnie umiera ojciec, zwykle wynika z tego nieszczęście" (s. 121), to trudno potraktować to jako zasadne wyjaśnienie ich zachowania. A transformacja Witmanów $\mathrm{w}$ dużym stopniu przypomina mroczną ewolucję Richarda z Czarnej ciszy. Bracia zaczynają dręczyć zwierzęta - polują na bezpańskie psy, rozciągają je na desce, po czym zaczynają rozkrawać je na kawałki: „Rozłupywali psu klatkę piersiową, [...] przyglądali się bijącemu sercu, brali w ręce ciepły, ruchliwy narząd i drobnymi ukłuciami niszczyli osierdzie i zastawki. Misterium bólu wywoływało w nich nienasyconą ciekawość" (s. 123). Stosując tak wymyślne tortury, pozbawiają życia koty, kurczęta i kaczki. Gdy nie dręczą zwierząt, spędzają czas z prostytutką-masochistką Irén, która wprowadza ich w świat erotyki. Chłopcy przeżywają z nią inicjację seksualna, a z każdym kolejnym stosunkiem stają się coraz bardziej agresywni: biją i maltretują dziewczynę. „Oto sens życia” (s. 128) - mówi jeden z braci. By pokazać Irén uwielbienie, chcą obdarować ją biżuterią swojej matki. Wczesnym rankiem wchodzą do sypialni rodzicielki, zabierają jej klejnoty, a następnie zabijają ją nożem.

Matkobójstwo można więc próbować odczytywać - podobnie jak poprzednie utwory - jako obraz destrukcyjnej energii budzących się popędów, które doprowadzają do katastrofy ${ }^{32}$, ciekawiej będzie jednak potraktować je jako metaforę rozwoju seksualności. Dręczenie zwierząt odpowiadałoby w sensie strukturalnym stadium oralnemu, podczas którego pod postacią niszczycielskiego gryzienia, plucia i fantazjowania o niszczeniu obiektu ujawnia się sadyzm dziecka; postępujące lekceważenie matki przez Witmanów, które po tym następuje, stanowiłoby zasadniczy punkt stadium analnego; stadium falliczne, gdy rośnie zainteresowanie dziecka tematami seksualnymi, symbolizowałoby nawiązanie relacji z Irén; stadium genitalne natomiast, kiedy dziecko chce ostatecznie odseparować się od rodziców, oddawałby w opowiadaniu moment morderstwa matki ${ }^{33}$. Ale i w tym przypadku wizję Csátha od Freuda różni pewna istotna kwestia, to

${ }^{32}$ M. Chmurski: Rąbek nieskończoności..., s. 351.

${ }^{33}$ M. Nowak, A. Gawęda, M. Janas-Kozik: Fizjologiczny rozwój psychoseksualny dzieci i młodzieży. "Seksuologia Polska” 2010, T. 8, nr 2, s. 65-67. 
znaczy działanie superego. Jeśli na ogół popędy seksualne ulegają dzięki niemu sublimacji i przekształcają się w społecznie akceptowalne formy, to $w$ przypadku braci Witmanów superego zawodzi lub po prostu nie istnieje, co potwierdzałoby wcześniejsze intuicje dotyczące poglądów Csátha na ludzką moralność. Być może jednak Csáth chciał w swoim opowiadaniu zobrazować lęk kastracyjny chłopców? W takim rozumieniu scena matkobójstwa nie byłaby przenośnią ich odseparowania się od rodzica - tyleż fizycznego, co psychicznego - lecz raczej symptomem postępującego (czy wręcz rozwiniętego) konfliktu edypalnego, który objawia się m.in. pod postacią sadystycznej nienawiści do matki, która zinkorporowała penis ojca $^{34}$. Utwór ten potraktować można w jeszcze inny sposób, a mianowicie jako formę (tekstualnej) kateksji, to znaczy wytworzenia przez autora za pomocą literackiej fikcji takiego wyobrażenia, które zaspokoiłoby dany popęd ${ }^{35}$. Czy chodziłoby tu jednak o pragnienie zabicia własnej matki, czy zaspokojenia perwersyjnych potrzeb seksualnych - trudno powiedzieć. Niemniej do takiego odczytania Matkobójstwa, a więc w kluczu (para)autobiograficznym, zachęcałyby inne katektyczne prozy Csátha, np. Spotkałem matkę, w której pisarz, posługując się erotycznym językiem, w niezwykle obrazowy sposób opisuje „młode dziewczęce piersi" (s. 37) swojej zmarłej matki, których nigdy nie dała mu ona do ssania. Morderstwo z Matkobójstwa można by $w$ takim rozumieniu interpretować jako próbę wyzwolenia się z popędu erotycznego wobec matki; kradzież jej biżuterii i ofiarowanie jej prostytutce byłyby równoznaczne z przeniesieniem popędu na inny obiekt.

Niemal wszystkie wątki z omówionych próz splatają się ze sobą w jednym z późniejszych opowiadań Csátha - Małej Emmie. Pojawiają się tu zarówno sceny maltretowania zwierząt, katastrofalne skutki niekontrolowania popędów płciowych, ale i przemoc zadawana dzieciom przez dorosłych. Obraz początkowo radosnego dzieciństwa pełnego zabaw i beztroski po raz kolejny ulega więc niepokojącej deformacji. Pierwsze pęknięcie pojawia się, gdy w szkole, do której uczęszczają główni bohaterowie, zatrudniony zostaje nowy nauczyciel, zwolennik kar cielesnych. Prowadzone przez niego lekcje upływają na nieprzerwanym biciu uczniów sprzeciwiających się jego autorytaryzmowi, a szczególnie znacząca wydaje się $w$ tym kontekście scena brutalnego pastwienia się nad jednym z wyjątkowo nieposłusznych chłopców, która ciągnie się przez kilka stron - staje

${ }^{34}$ M. Klein: Pisma. T. 2: Psychoanaliza dzieci..., s. 133.

${ }^{35}$ M. Libich: Opium, czyli katastrofa..., s. 344. 
się ona symbolem nie tylko dzieciństwa przepełnionego fizycznym cierpieniem, lecz także szerszą metaforą instytucjonalnej przemocy. Niejako równolegle narrator opowiada o uczuciu, jakie żywi do tytułowej Emmy, swojej przyjaciółki. O jej uwagę konkurować musi ze swoją siostrą Irmą, która ma do dziewczyny zaborczy stosunek podszyty homoerotycznymi uczuciami: „W czasie zabawy do znudzenia naprzykrzała się Emmie, wciąż ją obejmowała, całowała i ściskała" (s. 248). Csáth nie wyjaśnia, czy Irma odkrywa w ten sposób swoja tożsamość seksualną, czy raczej przenosi na przyjaciółkę tęsknotę za niedostępną matką. Prawdopodobniejsze wydaje się drugie wyjaśnienie. Potwierdza je podkreślona $w$ tekście nieobecność rodziców, którzy nie są w stanie przypilnować dzieci podczas zabawy, przez co wydarza się kolejna tragedia. Choć rodzeństwo obawia się przemocy, której doświadcza w szkole, jednocześnie jest nią oczarowane - na prowizorycznej szubienicy wspólnie wiesza więc najpierw psa, a potem Emmę.

Widać $\mathrm{w}$ tej prozie nieznaczne przesunięcia względem pozostałych opowiadań Csátha; rzuca ona nieco inne światło na to, jak pisarz wyobrażał sobie dzieciństwo. Choćby przemoc stosowana przez nauczyciela (który staje się symbolem szkolnej dyscypliny lub, ogólniej, instytucji służących wychowaniu) nie znajduje w innych prozach takiego wyrazu, podobnie zresztą jak konflikt między konkurującym ze sobą rodzeństwem. Mimo wszystko powtarzalność pewnych motywów, tematów i rozwiązań fabularnych u Csátha zwraca na siebie uwagę i nakazuje sądzić - co zresztą wyraźnie potwierdza uważna lektura poszczególnych próz - że jego literacka wyobraźnia opierała się na myśli psychoanalitycznej, pisanie było zaś sposobem, by ukazać ją w praktyce. Nierozwiązane konflikty edypalne, seksualne perwersje, skomplikowane relacje między rodzeństwem, a także pełen okrucieństwa stosunek wobec zwierząt, który zdaje się świadczyć o braku empatii - to podstawowe elementy imaginarium dzieciństwa $\mathrm{w}$ tej twórczości. Jeśli przyjrzeć się jej uważniej, osią każdego opowiadania okazuje się wczesna trauma: czy to w Świniobiciu, czy w Czarnej ciszy, czy wreszcie w Małej Emmie czyny i przejścia niedorosłych bohaterów mają opłakane skutki, które prześladują ich przez lata. Co gorsza, przed druzgocącymi wspomnieniami i odpryskami doznanych krzywd nie ma ucieczki; retrospektywne projekcje o nostalgicznym charakterze, będące formą wyparcia, okazują się wyjątkowo nietrwałe, a na ich podstawie nie sposób zbudować stabilnej tożsamości - rany otrzymane w dzieciństwie z biegiem lat stają się nieusuwalnymi bliznami. Csáth dowodzi, że na pierwsze spotkanie dziecka ze złem nie trzeba czekać długo. 
Można go albo doświadczyć, albo zadawać, nie sposób go jednak uniknać.

W tym sensie literatura Csátha jawi się jako wyzwanie. Nie tylko zmusza czytelnika do obcowania z brutalnymi obrazami cierpienia, nie tylko domaga się krytycznego, demitologizującego spojrzenia na dzieciństwo i jego pozornie sielskie lata, lecz przede wszystkim wymaga konfrontacji z własną przeszłością: rozpoznania tego, co traumatyczne, nieuświadomione i gotowe w każdej chwili wynurzyć się na powierzchnię.

\section{Bibliografia}

Ariès Ph.: Historia dzieciństwa. Przeł. M. Ochab. Marabut, Gdańsk 1995.

Bieńko M.: Międzygeneracyjny kontekst wychowania seksualnego w rodzinie z perspektywy młodego pokolenia, czyli kłopotliwe rozmowy rodziców i dzieci na temat intymności. „Studia Socjologiczne” 2017, nr 2, s. 213-240.

Chmurski M.: Błądzenie Gézy Csátha: między autobiografizmem, fikcja a autoanaliza. "Autobiografia" 2019, nr 2, s. 73-85.

Chmurski M.: Rąbek nieskończoności. „Literatura na Świecie” 2015, nr 3-4, s. 342-364.

Csáth G.: Dziennik chorej umysłowo. Przeł. W. Obiała. „Literatura na Świecie” 2015, nr 3-4, s. 309-341.

Csáth G.: Opium. Przeł. E. Cygielska [et al.]. Państwowy Instytut Wydawniczy, Warszawa 2016.

Cygielska E.: „Nyugat”. „Literatura na Świecie” 2002, nr 7-8-9, s. 255-293.

Cygielska E.: Csáth. W: G. Csáth: Opium. Przeł. E. Cygielska [et al.]. Państwowy Instytut Wydawniczy, Warszawa 2016.

Dybel P.: Samouwiedzenie w lustrze. Program antropologii psychoanalitycznej we wczesnych pismach Jacques'a Lacana. „Przegląd Filozoficzny” 1996, nr 4, s. $7-18$.

Hurnikowa E.: Zmierzch w literaturze i malarstwie austriackim na przełomie XIX i XX wieku. „Świat i Słowo” 2013, nr 2, s. 187-193.

Klein M.: Pisma. T. 2: Psychoanaliza dzieci. Przeł. M. Lipińska, M. Żylicz, H. Grzegołowska-Klarkowska. Wstęp W. Hańbowski. Gdańskie Wydawnictwo Psychologiczne, Gdańsk 2007.

Leszczyński G.: Kulturowy obraz dziecka i dzieciństwa w literaturze drugiej połowy XIX $i$ w XX wieku. Wydawnictwo Wydziału Polonistyki Uniwersytetu Warszawskiego, Warszawa 2006.

Libich M.: Opium, czyli katastrofa. „Literatura na Świecie” 2019, nr 9-10, s. 340-349.

Magnone L.: Dywan z Bukowiny. Drogi rozpowszechniania się freudyzmu w Europie Środkowej. W: Problemy literatury i kultury modernizmu w Europie Środkowo-Wschodniej (1867-1918). T. 1: Teksty doświadczenia. Red. E. Paczoska, 
I. Poniatowska, M. Chmurski. Wydawnictwa Uniwersytetu Warszawskiego, Warszawa 2017.

Nowak M., Gawęda A., Janas-Kozik M.: Fizjologiczny rozwój psychoseksualny dzieci i młodzieży. „Seksuologia Polska” 2010, T. 8, nr 2, s. 64-70.

Rose J.: The Case of Peter Pan or The Impossibility of Children's Fiction. University of Pennsylvania Press, Philadelphia 1993.

Wiedemann A.: Człowieczeństwo i czary. https://www.dwutygodnik.com/artykul/ 6662-czlowieczenstwo-i-czary.html [dostęp: 14.03.2021].

Maciej Libich - doktorant literaturoznawstwa w Szkole Doktorskiej Nauk Humanistycznych. Laureat Diamentowego Grantu (2019). Bada rękopisy dzienników wojennych Leopolda Buczkowskiego, Anny Pogonowskiej oraz Jerzego Kamila Weintrauba. Zajmuje się polską i węgierską literaturą, a także diarystyką XX wieku, pisze również o współczesnej polskiej prozie. Współredaktor monografii Języki literatury wspótczesnej (Wydawnictwa Uniwersytetu Warszawskiego; w druku) oraz Zapisywanie wojny. Dzienniki z lat 1939-1945 (Wydawnictwa Uniwersytetu Warszawskiego; w druku). Współpracuje m.in. z „Literaturą na Świecie”, „Dwutygodnikiem”, „Polityką”. Założył i redaguje kwartalnik literacki „Wizje”.

e-mail: maciejlibich@gmail.com 